\title{
How does Emotional Intelligence Relate to Transformational Leadership, Creativity, and Job Performance?
}

\author{
Md. Sahidur Rahman ${ }^{1}$, Shameema Ferdausy ${ }^{1}$, Md. Al-Amin ${ }^{2 *}$ \& Refa Akter ${ }^{3}$ \\ ${ }^{1}$ Professor, Department of Management, University of Chittagong, Chattogram 4331, Bangladesh \\ ${ }^{2}$ Lecturer, Department of Business Administration (Management), Mawlana Bhashani Science and Technology University, \\ Santosh, Tangail-1902, Bangladesh \\ ${ }^{3}$ Lecturer, Department of Management, Rangamati Science and Technology University, Rangamati 4500, Bangladesh \\ *Corresponding author: alaminmgtcu@gmail.com \\ https://riiopenjournals.com/index.php/society sustainability/index
}

Doi: $\underline{\text { https://doi.org/10.38157/society sustainability.v2i1.64 }}$

Citation: Rahman, M.S., Ferdausy, S., Al-Amin, M., \& Akter, R. (2020). How does Emotional Intelligence Relate to Transformational Leadership, Creativity, and Job Performance? Society \& Sustainability, 2(1), 1-15. Doi: https://doi.org/10.38157/society sustainability.v2i1.64

\section{Research Article}

\begin{abstract}
This study aims to investigate the relationships between emotional intelligence (EI), and transformational leadership (TL), creativity (CR), and job performance (JP) of the managers as perceived by the subordinates. Cross-sectional survey research is the primary research design for the study. A printed survey instrument is used to collect data from 189 working MBA students in Chattogram city using a purposive sampling technique. The respondents provide information about EI, TL, CR, and JP of their managers. We employed descriptive statistics, bivariate correlation, and regression analysis to analyze the obtained data. The findings of the study show that there is a positive correlation between EI and TL ( $r=$ 0.68). Again, a firm affinity is observed between EI and $C R(r=0.62)$. Furthermore, a strong relationship is found between EI and JP $(r=0.73)$. This study imparts the message to the organizations that they should focus on upgrading the EI competencies of the managers who intend to be transformational leaders and willing to show their credibility in creativity and superiority in job performance. The purposive sampling technique was adopted which is one of the major limitations of this study.
\end{abstract}

Keywords: Emotional intelligence, transformational leadership, creativity, job performance.

\section{Introduction}

Emotional intelligence (EI) is one of the most studied phenomena not only in psychology but also in the field of organizational behavior (Rahman, 2010; 2018). It received wide acceptance among academics and researchers in the last ten years. Goleman (1995) who is regarded as one of the pioneers of this discipline coined that EI was twice as important as IQ (p. 34). EI is a 
significant component for an individual's enrichment as well as for developing leadership excellence. It comprises of self-awareness, self-management, social skills, and relationship management which are the sine-qua-non of leadership (Goleman, 1998a, p. 94). Goleman, Boyatzis, and McKee (2002) have argued that EI is positively linked to one's leading capacity and effectiveness. Goleman (1998a) also recommended that "the most effective leaders are alike in one crucial way; they all have a higher degree of what has come to be known as emotional intelligence" (p. 94). Other studies proposed that it is vital for fruitful leadership (Cooper \& Sawaf, 1998; Rahman \& Ferdausy, 2014), creativity (Sukumaran \& Sivelingam, 2012), and Job Performance (JP) (Druskat \& Wolff, 2001; Rahman, Ferdausy, \& Karan, 2013). Huy (1999) narrated that individuals' coping ability and resilience get easier through it. Furthermore, according to Dulewicz and Higgs (2003), it has a partial contribution to one's career progress.

Studies on leadership demonstrated that EI plays an effective role in Transformational Leadership (TL) by motivating subordinates and establishing a strong conducive relationship (Bass 1997; Goleman, 1998a; Biswas, Ferdausy, \& Rahman, 2018). Transformational leaders must exhibit emotional attachment to their values and beliefs while contacting their followers (Bass, 1985). They exert emotion in communicating vision and extracting feedback from their followers (Ashkanasy \& Tse, 2000; Lewis, 2000). According to George (2000), leaders employ positive emotions for making major organizational decisions. Gill (2002) revealed that transformational leaders require EI and soft skills while managers need managerial skills. Ciarrochi, Forgas, and Mayer (2006) argued that EI carries a magnificent role in both managerial and leadership effectiveness. Many studies observed that there is a clear positive correlation between EI and leadership effectiveness (Barling, Slater, \& Kelloway, 2000; Gardner \& Stough, 2002; Rahman, Ferdausy, \& Uddin, 2012a).

Similarly, it is narrated that EI is important for generating creativity (CR). Emotionally intelligent individuals can be more creative than others. Franken (1993) referred to CR as the ability to bring new ideas, or substitutes, or products that may be the essential solution to the existing problems, exchanging with others, and giving amusements to oneself and others. The inevitability of CR is considered for three reasons: i) to encourage variety and complexity, ii) to exchange new ideas and values, and iii) to bring creative solutions (Franken, 1993). Therefore, CR emphasizes challenging but implementable ideas, novelty, new styles, and new chances. A man without $C R$ gets stuck in back-dated practices, formats, models, notions, and assumptions (Akinboye, 2003). CR can be described as the summation of intellectual acts, facts, inspiration, analytical reasoning, identity, and atmosphere (Sternburg \& Lubart, 1996). Organizational practices (Tesluk, Farr, \& Klein, 1997), organizational atmosphere (Ekvall, 1996), leading style (Zhang \& Bartol, 2010), task performance (Kuncel, Hezlett, \& Ones, 2004), entrepreneurship development (Okpara, 2007), EI (Sukumaran \& Sivelingam, 2012) and many such variables are connected to CR. Hence, it can be mentioned that CR is a knowledge-based process through which one can demonstrate his innovation, creativity in bringing new products, ideas, and process transmission. That is why, CR is crucial for the development of emotion recognition power and JP of managers (Sukumaran \& Sivelingam, 2012). 
Likewise, it was recommended that EI is the antecedent of JP and emotionally intelligent individuals accomplish their jobs more successfully than those with low EI (Goleman, 1998a; 1998b; Watkins, 2000). Several research findings have shown that EI has a significant influence on JP (Brotheridge, 2006; Cherniss \& Adler, 2001; Rahman \& Ferdausy, 2014). It generally does base on how employees could use and able to recognize their emotions to simplify task accomplishments (George \& Brief, 1996). Employees could use both positive and negative emotions to take the advantage to upgrade JP (Sy, Tram, \& O'Hara, 2006). Based on the above discussion the present study attempts to investigate the role of EI on TL, CR, and JP in the context of Bangladesh. As far as our knowledge goes, this is a pioneering study on the contextual ground.

\section{Literature Review}

\subsection{Emotional Intelligence}

EI has been explained in different ways by different authors. Salovey and Mayer (1990) were the first to define it. They refer it as a part of social intelligence indicating the ability of monitoring self and others' emotions and feelings, distinguishing among them, and applying this knowledge to direct one's way of managing. Goleman (1998b) defines EI as the ability to identify one's own and other's feelings, and effectively handling the emotions. In fact, EI is involved with several non-cognitive skills, abilities, or competencies that can influence an individual's capacity. Bar-On (1997) considers EI as a combination of pathological, personal, and communal skills and abilities that can shape an individual's capability to adapt emerging needs and forces of the environment (p. 14).

An individual's EI can be assessed by EI tools such as the Emotional Quotient Index (EQI) developed by Rahim et al., (2002) as used in prior studies. It is used to evaluate the five elements of EI, i) self-awareness, ii) self-regulation, iii) motivation, iv) empathy and v) social skills. These elements are the revised form of the main version provided by Goleman (1995). It is a 40-item instrument designed to measure subordinates' perceptions of their respective managers' EI. Descriptions of these five components are as follows (Rahim et al., 2002, p.305):

Self-awareness: It indicates the ability to be aware of the emotions, moods, and impulses one is encountering and the reason behind it. This also includes understanding the effects of his or her feelings on others.

Self-regulation: It is associated with the ability to keep self-emotions and impulses under control, to remain static in vulnerable situations, and to keep consistency in emotional behaviors.

Motivation: It denotes the ability to keep track of goals despite obstacles, to go beyond the fear of defeat, fear of forgoing current yield, and to get ready to adapt to the changes for goal attainment.

Empathy: It represents the ability to realize the emotions and feelings of others receiving in any form either verbal or non-verbal, to assist emotionally when required, and being able to set linkage between others' emotions and behaviors. 
Social skills: It refers to the ability to work with problems, managing self or others' inadmissible emotions that prohibit cooperation, and applying sagacity and diplomacy to successfully handling conflicts.

\subsection{Transformational Leadership}

TL was first coined by Downton (1973) in his work on rebel leadership. Burns (1978), noted for providing the TL stream, distinguished between transactional leadership (TSL) and TL in political leaders. Later, Bass (1985) worked on Burn's thoughts of TL and TSL and elaborated his work proposing three characteristics of TL: charisma, intellectual stimulation, and individualized consideration. Moreover, Bass and Avolio (1990; 1994) extended this by offering a four-factor model adding one new variable: inspirational motivation. Afterward, the factor charisma was replaced with idealized influence by the study of Antonakis, Avolio, and Sivasubramaniam (2003).

Transformational leaders stimulate others to accomplish beyond what is desired and what they consider doable (Bass \& Riggio, 2006). They set visionary goals and often attain superior performances and wish to have highly loyal and committed followers. There are four components of TL conferred by Bass, Avolio, Jung, and Berson (2003, p. 208) as follows:

Idealized influence: The leaders are involved in getting followers to know about organizational beliefs, values, ethics, and principles along with participation in taking a risk with them. They are praised, honored, and trusted by the followers. Followers are encouraged and intended to emulate them.

Inspirational motivation: Leaders inspire their followers by setting challenging but meaningful goals. As a result, followers try to exert team spirit enthusiastically and work for achieving institutional objectives by all their endeavors. The leader encourages followers to envision attractive future states, which they can ultimately envision for themselves.

Intellectual stimulation: The culture of questioning backdated systems, rethinking problems, logical arguments, searching new ways, and encouraging new approaches are nurtured to instigate followers being innovative and creative. In this system, none laugh at others' mistakes. Followers participate in addressing problems with their updated devising solutions.

Individualized consideration: Leaders concentrate on each individual's development acting as an instructor. Followers are supported by ensuring a favorable atmosphere and are provided with the opportunity to grow by creating more learning and improvement scope. They focus on individual differences to motivate followers.

\subsection{Creativity}

Creativity is one's ability to bring new concepts by mixing, altering, and redesigning existing concepts but it is not merely generating something out of nothing. It is often considered as a genetically obtained trait of an individual. CR is a thought, the power of accepting alteration and freshness, an intention to work with ideas and likelihood, readiness to change the status quo, the nature of appreciating and taking pleasure in good while searching for new paths to ameliorate it (Okpara, 2007). It is the dexterity of originating solution to the problems with the 
help of supposition and logic (Okpara, 2007). Within every individual, CR is a function of three elements such as i) expertise, ii) creative thinking, and iii) motivation. Expertise is a combination of technical, procedural, and intellectual knowledge, which is the basis of creativity. Individuals with the capability and expertise in specific sectors or fields can increase creative outcomes. Creative thinking means the way people deal with problems and come out with a solution from different angles. Motivation is the willingness to act on something attractive, thrilling, gratifying, and personally demanding or appealing. It is an intrinsic matter which activates an individual for creative achievement.

Every person has creativity to some extent and is not equal in magnitude. For example, Einstein, Edison, Picasso, and Mozart, as well as some other individuals, possessed exceptional CR. This is very rare in reality and less than one percent of individuals possess such $C R$, ten percent of individuals have high $\mathrm{CR}$, and about sixty percent of individuals possess lower or medium CR (Robbins, 2005). This reflects that human being has the potential of being creative, at least, to some extent.

Currently, most of the managerial decisions need distinctive and new solutions. Often, it is quite troublesome to look for solutions conventionally. We frequently use our logical thinking power to introduce new solutions. But, it is only the extension of an existing one instead of being completely distinctive. So, it does not make people creative. Consequently, it is an urgency of the present situation to find out creative problem-solving mechanisms due to the narrow scope of logical thinking. At present, most of the organizations are concerned about being creative for ensuring their growth. So, CR has a remarkable contribution to business sectors (Seidel \& Rosemann, 2008).

\subsection{Job performance}

Performance is the amount of attainment a person has had with his/her efforts in doing a job (Hellriegel, Jackson, \& Slocum, 1999). It refers to the acts and behaviors controlled by a person and which can cooperate attaining organizational goals (Rotundo \& Sackett, 2002). An effective performance management system should include all dimensions of work outcomes that are connected to the presence of an organization and the instruments through which it reaches its success and advancements (O'Regan, Ghobadian, \& Sims, 2005).

Several previous studies have recapitulated different kinds of performance which comprise team performance (Koman \& Wolff, 2008), job performance (Dries \& Pepermans, 2007), and management performance (Slaski \& Cartwright, 2002). JP is mostly used as a performance indicator in the organizational work setting. It usually indicates the level of effort a person exert and how well they do it. According to Campbell (1990) and his colleagues (Campbell, McCloy, Oppler, \& Sager, 1993), JP is an individual-level variable. Different researchers (Tsui, Pearce, Porter, \& Tripoli, 1997; Welbourne, Johnson, \& Erez, 1998) have recommended a variety of factors including the amount, quality, and appropriateness of the work; proficiency and work grade of the employee; the degree of the fight for superior quality and goal attainment by the employees, and so forth to measure JP of an individual. 


\section{Hypotheses Development}

\subsection{Emotional Intelligence and Transformational Leadership}

EI as an antecedent for TL is stated in many previous research findings (Barbuto \& Burbach, 2006; Rahman, Ferdausy, \& Uddin, 2012b; Rahman, 2018). Transformational leaders intensely vitalize followers to accept shared responsibility and utilize mental state to assist followers' sentimental connections and engagement along with employing affinity to find out followers' desires and basic convictions (Burns, 1978). Furthermore, transactional leaders' activities escalate the spirituality level of followers and persuade them for maximum performance (Bass \& Avolio, 2000). It is asserted that transformational leaders are involved in the act of applying feelings in disseminating a vision and for obtaining feedback from followers (Ashkanasy \& Tse, 2000; Lewis, 2000; Biswas, Rahman, \& Ferdausy, 2017). It is expected that leaders will spur inert the desires of the employees by inspiring followers to perform above the standard level. For being capable of utilizing members' inner feelings, transformational leaders require better sensory consciousness along with dexterity (Weinberger, 2003). Therefore, we have stated the first hypothesis as,

\section{H1: There is a positive relationship between EI and TL}

\subsection{Emotional Intelligence and Creativity:}

Various studies (Olatoye, Akintunde, \& Yakasai, 2010; Sukumaran \& Sivelingam, 2012; Vijaykumar \& Govindaraju, 2012) observed that EI and CR have a significant interrelationship. Sukumaran and Sivelingam (2012) conducted a research to identify the correlation between EI and $\mathrm{CR}$ on task performance and commitment. They found that the Administrators and staff members who deal with their feelings become highly creative and can support the organizations to conquer rigid and long-established obstacles in figuring out new techniques. Dadvar, Mohamadrezaii, and Fathabadi (2012) further pointed out an affirmative and considerable correlation between EI and CR based on the work on high school students. Thus, we have proposed the following hypothesis:

\section{H2: There is a positive relationship between EI and CR.}

\subsection{Emotional intelligence and job performance}

Those who are intelligent in terms of emotions can adopt deep-rooted inspiration and perceive how their feelings influence them and their JP (Goleman et al., 2004).It was found that top-level managers with greater EI accomplish their tasks in more systematic ways (Carmeli, 2003). Emotionally intelligent staffs are equally resilient, sincere, ethical, original, and conscientious about coping up with the rapidly changing environment to accomplish their jobs smoothly (Rahman, Ferdausy, \& Karan, 2012c). Engineers with the extra demonstrative capability of their feelings act as top achievers compared to the other colleagues (Goleman, 1998b). Moreover, staff members having tremendous EI have immense individual standards that encourage them to explore persistently advanced performance, to introduce measurable and difficult but achievable objectives for generating better future potentiality (Slaski \& Cartwright, 2002). Additionally, empathetic managers are apt in adjusting with disparate employees and to tune in 
to a wide range of emotional signals, accrediting them to perceive the emotions to individual or organization to retain the quantity, aspects and the efficiency of distinct responsibility (Rahim \& Marvel, 2009; Rahman, 2018). Accordingly, we have proposed the following hypothesis:

Hypothesis 3: There is a positive relationship between EI and JP.

\section{Research Framework}

Based on the literature review and hypotheses considered for the study, the following research framework is envisioned to illustrate the connections among EI, TL, CR, and JP:

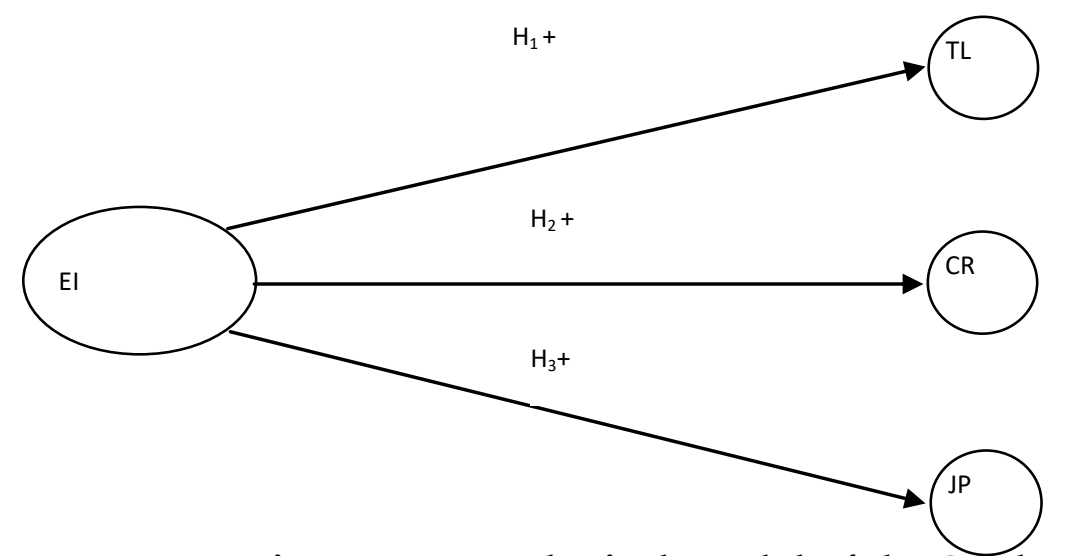

Figure 1: Hypothetical Model of the Study

Note: $\mathrm{EI}=$ emotional intelligence; $\mathrm{TL}=$ transformational leadership; $\mathrm{CR}=$ creativity, and $\mathrm{JP}=$ job performance

\section{Research Methods}

\subsection{Participants}

This research was conducted with samples of 189 working MBA students who appraise their managers' EI, TL, CR, and JP. Raters were engaged in diverse enterprises during the time of pursuing evening MBA programs at different private universities in Chattogram city. The respondents were assured that the information collected would be kept confidential and would be used only for academic purposes. Respondents' age range was from 25 years to 47 years, with an average of $31.68(\mathrm{SD}=6.72)$ years. Of them, $119(63 \%)$ were male while $70(37 \%)$ were female. The number of mid-level employees was 125 (66\%) while first-level employees were 64 (34\%). All of them had a high educational qualification. 134 (71\%) respondents completed a master's degree while 55 (29\%) respondents obtained a bachelor's degree from various disciplines. The respondents were found from different business units including manufacturing $(49,26.1 \%)$, merchandising $(16,8.5 \%)$, sales and retail $(30,15.3 \%)$, education $(19,10.2 \%)$, healthcare $(16,8.5 \%)$, financial services $(29,15.2 \%)$, and service industry $(30,16.2 \%)$.

\subsection{Survey Instruments}

The study used previously developed scales for measuring the selected variables.

Emotional Quotient Index: Emotional Quotient Index (EQI) developed by Rahim et al. (2002; 2006) was adopted to estimate EI for appraising the respondents' perceptions of their corresponding managers' EI. The EQI (Rahim et al., 2002; 2006) is a combination of forty items 
to construct a measurement tool for EI. These components were assessed on a 5-point Likert scale starting at 5 (Strongly Agree) to 1 (Strongly Disagree). A higher level of score indicates a higher level of EI of the manager. The reliability of the EQI found in this study was .93. Sample elements for EQI were such as 'My manager is well aware of his or her moods', 'My manager stays focused on goals despite setbacks', 'My manager handles emotional conflicts with tact and diplomacy' etc. Multifactor Leadership Questionnaire: TL was assessed with the help of the Multifactor Leadership Questionnaire (MLQ 5X; Bass \& Avolio, 2000). We utilized twenty items of MLQ 5X (Bass \& Avolio, 2000) to find out the TL of managers. This scale was anchored on a 5-point Likert scale beginning from 0 (not at all) to 4 (frequently, if not always). The reliability of the TL for the current study was 0.86. Sample items include, 'My manager instills pride in me for being associated with him/her', 'My manager talks optimistically about the future', and 'My manager spends time teaching and coaching' etc.

Creativity: Creativity (CR) was measured with the scale developed by Zhou and George (2001), which include thirteen items for identifying the respondents' perceptions of their managers' creativity. Sample items were such as "My manager suggests new ways to achieve goals or objectives', 'My manager promotes and champions ideas to others', 'My manager comes up with creative solutions to problems', etc. The response scale ranged from 1 (Strongly disagree) to 5 (Strongly agree). A higher score indicates a greater creative capability of the managers. The Cronbach alpha of the creativity for the current study was 0.87 .

Job Performance: Job performance (JP) was evaluated with the six items initiated by Tsui et al., (1997). The sample items were 'My manager's quantity of work is much higher than average', 'My manager's quality of work is much higher than average' etc. The response scale ranged from 1 (Strongly disagree) to 5 (Strongly agree). The reliability of the JP scale for the current study was 0.89 .

\subsection{Data Collection Procedure}

A purposive sampling technique was used to choose the sample. In order to collect data, 270 printed questionnaires were distributed among the working MBA students of four private universities while they were in the classroom. The authors approached the respondents and explained the objectives of the study along with the steps to accomplish the printed survey. Generally, respondents spent half an hour to fill the distributed questionnaires. A total of 189 (70\%) completed responses were received. Data were analyzed by SPSS (18.0 version).

\subsection{Reliability of Scales and Validity of Data}

The reliability of the items employed in the study was measured by Cronbach's alpha. It was found that the Cronbach's alpha of the EI, TL, CR, and JP of this research were 0.90, 0.85, 0.88, and 0.90 respectively. Thus, all of the measurements were highly reliable. The validity refers to the degree to which variations in realized measurement outcome reveal authenticity among objects on aspects assessment instead of a methodological or irregular error (Saunders, Lewis, \& Thornhill, 2011). The measurement validities (EI, TL, CR, and JP) were assured through the significant amount of reviews in other countries along with Bangladesh (Rahim et al., 2002; 
2006; Rahman et al. 2012a; 2012b; Bass \& Avolio, 1995; 2000; Tsui et al., 1997; Bhattacharjee \& Rahman, 2016).

\section{Results}

The mean, standard deviation, and correlation for EI, TL, CR, and JP are shown in Table 1. The mean and standard deviation for EI and TL (Rahman \& Ferdausy, 2014; Rahman, 2018), and CR (Bhattacharjee \& Rahman, 2016), and EI and JP (Rahman et al., 2013; Rahman, 2018) had similarity with prior researches.

Table 1: Means, Standard Deviations, Reliabilities, and Correlations between Variables

\begin{tabular}{|c|c|c|c|c|}
\hline \multirow{2}{*}{ Particulars } & \multicolumn{4}{|c|}{ Variables } \\
\hline & EI & TL & $\mathrm{CR}$ & JP \\
\hline Mean & 3.85 & 3.72 & 3.74 & 3.88 \\
\hline SD & 0.75 & .73 & 0.76 & 0.81 \\
\hline A & 0.90 & 0.85 & 0.88 & 0.90 \\
\hline Correlations with EI & 1.00 & $0.67^{* *}$ & $0.64^{* *}$ & $0.78^{* * *}$ \\
\hline
\end{tabular}

${ }^{* *}$ Correlation is significant at the 0.01 level (2-tailed). $\mathrm{n}=189$; $\mathrm{EI}=$ emotional intelligence; $\mathrm{TL}=$ transformational leadership; $\mathrm{CR}=$ creativity, and $\mathrm{JP}=$ job performance

Experiment of the Table 1 reveals that EI is found to connect substantially with TL, CR, and JP (r $=0.67, \mathrm{p}<0.01 ; \mathrm{r}=0.64, \mathrm{p}<0.01$, and $\mathrm{r}=0.78, \mathrm{p}<0.01)$ respectively. Hence, it states that all three hypotheses were supported by the results.

Table 2a: Regression Analysis of Demographic Characteristics with EI, TL, CR, and JP

\begin{tabular}{|c|c|c|c|c|c|c|c|c|c|c|c|c|}
\hline \multirow[t]{2}{*}{ Covariates } & \multicolumn{4}{|c|}{$\begin{array}{l}\text { Co-efficients } \\
(\beta)\end{array}$} & \multicolumn{4}{|l|}{$\begin{array}{l}\text { S.E. } \\
(\beta)\end{array}$} & \multicolumn{4}{|c|}{$\begin{array}{l}\text { Value of } \\
\text { t-statistic }\end{array}$} \\
\hline & EI & $\mathrm{TL}$ & CR & JP & EI & $\mathrm{TL}$ & CR & $\mathrm{JP}$ & EI & TL & CR & JP \\
\hline Gender & .11 & .10 & .14 & .25 & .17 & .16 & .14 & .24 & .15 & .58 & .99 & 1.1 \\
\hline Age & .16 & .21 & .11 & .21 & .13 & .12 & .13 & .11 & .32 & .16 & .61 & .93 \\
\hline Tenure & .19 & .31 & .21 & .22 & .12 & .21 & .12 & .13 & .43 & .53 & .31 & .73 \\
\hline Position & .12 & .22 & .11 & .38 & .14 & .14 & .12 & .20 & .58 & .16 & .98 & 1.8 \\
\hline Education & .21 & .16 & .12 & .15 & .17 & .16 & .18 & .15 & .13 & .61 & .20 & 1.0 \\
\hline
\end{tabular}

** Correlation is significant at the 0.01 level; $\mathrm{n}=189$; $\mathrm{EI}=$ emotional intelligence; $\mathrm{TL}=$ transformational leadership; $\mathrm{CR}=$ creativity, and $\mathrm{JP}=$ job performance

Table 2b: Regression Analysis of Demographic Characteristics with EI, TL, CR, and JP

\begin{tabular}{|c|c|c|c|c|c|c|c|c|}
\hline Covariates & \multicolumn{4}{|c|}{ Value of $\mathrm{R}^{2}$} & \multicolumn{4}{|c|}{ Value of F-statistic } \\
\hline Gender & EI & $\mathrm{TL}$ & $\mathrm{CR}$ & $\mathrm{JP}$ & EI & $\mathrm{TL}$ & CR & $\mathrm{JP}$ \\
\hline Age & \multirow{3}{*}{.03} & \multirow{3}{*}{.02} & \multirow{3}{*}{.02} & \multirow{3}{*}{.04} & \multirow{3}{*}{.21} & \multirow{3}{*}{.28} & \multirow{3}{*}{.61} & \multirow{3}{*}{1.45} \\
\hline Tenure & & & & & & & & \\
\hline \begin{tabular}{|l|} 
Position \\
Education
\end{tabular} & & & & & & & & \\
\hline
\end{tabular}

** Correlation is significant at the 0.01 level; $\mathrm{n}=189$; $\mathrm{EI}=$ emotional intelligence; $\mathrm{TL}=$ transformational leadership; $\mathrm{CR}=$ creativity, and $\mathrm{JP}=$ job performance 
In Table $2 b$, it is observed that the socio-demographic characteristics (e.g. gender, age, tenure, position, education, and organization) explain only $3 \%, 2 \%$, and $2 \%$ variances in EI, TL, CR, and JP respectively. It denotes that a greater amount of variances in EI, TL, CR, and JP were unexplained. The existence of unexplained variances points out that there might be other potential implied variables that could account for variations in EI, TI, CR, and JP.

Table 3: Regression Analysis regarding TL, CR, and JP

\begin{tabular}{|lllll|}
\hline \multirow{2}{*}{$\begin{array}{l}\text { Independent } \\
\text { Variable }\end{array}$} & Particulars & \multicolumn{3}{l|}{ Dependent Variables } \\
\cline { 2 - 5 } & & $\mathrm{TL}$ & $\mathrm{CR}$ & $\mathrm{JP}$ \\
\hline \multirow{3}{*}{ EI } & Co-efficient $(\beta)$ & .73 & .42 & -.47 \\
\cline { 2 - 5 } & S.E. $(\beta)$ & .05 & .05 & -.09 \\
\cline { 2 - 5 } & Value of t-statistic & $18.66^{* *}$ & $16.62^{* *}$ & $24.91^{* *}$ \\
\cline { 2 - 5 } & Value of $\mathrm{R}^{2}$ & 0.46 & 0.39 & 0.53 \\
\cline { 2 - 5 } & Value of F -statistic & $227.48^{* *}$ & $174.29^{* *}$ & $274.06^{* *}$ \\
\hline
\end{tabular}

** Correlation is significant at the 0.01 level; $\mathrm{n}=189$; $\mathrm{EI}=$ emotional intelligence; $\mathrm{TL}=$ transformational leadership; $\mathrm{CR}=$ creativity, and $\mathrm{JP}=$ job performance

Examination of Table 3 indicates that about $46 \%, 39 \%$, and 53\% of the variances in TL, CR, and JP were explained by EI respectively. Although a large portion in TL and CR were unexplained, it has been suggested that the EI might be used in predicting TL, CR, and JP.

\section{Discussions}

The research is intended to investigate the interconnections among EI, TL, CR, and JP of the managers' as perceived by their subordinates. Initially, the goal of this study was to figure out the connections of EI with TL as perceived by the respondents. The first hypothesis states that EI and TL have an affirmative connection. The result approves the view. It implies that leaders with better sensory capacities and emotional readiness will create extraordinary influence over the followers' to perform at an outstanding level. Therefore, it is expected that individuals with highly capable of EI have a higher potential to become transformational leaders. This finding is in line with that of the prior studies (Barbuto \& Burbach, 2006; Rahman et al., 2012b; Rahman, 2018). This result also endorses that EI becomes a considerable factor to find out TL.

Secondly, this survey had the intention to examine the linkage between EI and CR as perceived by the raters. The second hypothesis stated that EI and CR had an affirmative linkage. The outcome of this experiment also portrays a positive relationship between these two variables ( $\mathrm{r}$ $=0.64$ ). Therefore, managers who can maintain consistency in feelings; they are likely to be creative to a greater extent. They can also motivate subordinates for bringing out novel thoughts toward achieving the organizational objectives. The current findings align with that of the prior studies (Vijaykumar \& Govindaraju, 2012; Bhattacharjee \& Rahman, 2016).

Finally, this study analyzes the connection of EI with JP as perceived by the respondents. The result reveals that EI and JP have an affirmative linkage $(r=0.78)$. The reason behind this is that emotionally intelligent managers have a high level of dexterity to adapt and execute 
incompatible employees and capable of adapting with a wide range of emotional signals that enable the employees to adjust with their organizations and thus lead to better performances. Prior investigation toward EI and JP led persistency with the current survey (Rozell et al., 2006; Rahman et al., 2013). If employees have a higher degree of EI, they presumably show better JP.

\section{Implications for Management}

The present study is a pioneering attempt to investigate the impact of EI on TL, CR, and JP in the context of Bangladesh. The research findings of this study might help business executives understand the potential impact of EI on TL, CR, and JP. The outcome of this experiment will drive them to tie EI to achieve their desired goals successfully. EI is crucial for the managers to become effective transformational leaders, to ensure creativity and to sustain above-average job performance. It implies that the organizations should invest in training and development programs for EI, TL, and CR. This will lead to tremendous growth in employee job performance. Besides, the authority needs to advocate and compensate for the employees' creative endeavors. It can be achieved by the means of joint efforts of the employees. Furthermore, this research provides significant insight into managers that they should develop their EI capability in order to enable and advance their TL abilities. And, last but not the least, this study makes a significant contribution in the field of organizational behavior underpinning remarkable empirical support for EI.

\section{Limitations and Direction for Future Research}

There are some limitations to this research. The significant constraint was adopting a purposive sampling approach that impairs the generalizability of this study. However, a random sampling technique could have been a better choice of the study. The small sample size $(n=189)$ is another constraint of the research. A larger sample is required for better assessment of the connections among EI, TL, CR, and JP. Lastly, using a 360-degree evaluation is missing in the study. Therefore, a 360-degree measurement tool is required for studying the relationships among EI, TL, CR, and JP where the subordinates, peers, and customers can rate the subject to find out the exact attributes.

Author Contributions: Md. Sahidur Rahman, Shameema Ferdausy, Md. Al-Amin, and Refa Akter conceived the idea; Md. Al-Amin and Refa Akter collected data and all the authors jointly wrote the paper.

Conflict of interest: The authors declare no conflict of interest.

\section{REFERENCES}

Akinboye, J.O. (2003). Creativity, Innovation, and Success. Ibadan: Sterling Horden Publishers (Nig.) Ltd.

Antonakis, J, Avolio, B. J. \& Sivasubramaniam, N. (2003). Context and leadership: an examination of the nine-factor full-range leadership theory using the Multifactor Leadership Questionnaire. The Leadership Quarterly, 14, 261-295. 
Ashkanasy, N., \& Tse, B. (2000). Transformational leadership as management of emotion: A conceptual review. Emotions in the workplace: Research, theory, and practice, 221-235.

Barbuto, J. J. E. \& Burbach, M. E. (2006). The Emotional Intelligence of Transformational Leaders: A Field Study of Elected Officials. Journal of Social Psychology, 146, 51-64.

Barling, J., Slater, F. \& Kelloway, E. K. (2000). Transformational leadership and emotional intelligence: an exploratory study. Leadership \& Organization Development Journal, 21, 157-161.

Bar-On, R. (1997). The Emotional Quotient Inventory (EQ-i): A test of emotional intelligence, Toronto, Canada, MultiHealth Systems, Inc.

Bass, B. M. (1985). Leadership and performance beyond expectations, New York, Free Press.

Bass, B. M. \& Avolio, B. J. (1990). The implications of transactional and transformational leadership for individual, team, and organizational development. In Woodman, R. W. \& Pasmore, W. A. (Eds.) Research in organizational change and development. Greenwich, CT, JAI Press.

Bass, B. M. E Avolio, B. J. (1994). Improving Organizational Effectiveness Through Transformational Leadership, London, Sage.

Bass, B. M. \& Avolio, B. J. (1995) Multifactor Leadership Questionnaire for Research, Palo Alto, CA, Mind Garden.

Bass, B. M (1997). Does the transactional-transformational leadership paradigm transcend organizational and national boundaries? American Psychologist, 52,130-139.

Bass, B. M. \& Avolio, B. J. (2000). MLQ Multifactor Leadership Questionnaire, Redwood City, CA, Mind Garden.

Bass, B. Avolio, B. Jung, D. \& Berson, Y. (2003). Predicting unit performance by assessing transformational and transactional leadership. Journal of Applied Psychology, 88, 207-218

Bass, B., \& Riggio, R. (2006). Transformational leadership: Lawrence Erlbaum.

Batey, M., \& Furnham, A. (2006). Creativity, intelligence, and personality: A critical review of the scattered literature. Genetic, Social, and General Psychology Monographs, 132(4), 355-429.

Bhattacharjee, S. \& Rahman, M.S. (2016). Assessing the Relationship among Emotional Intelligence, Creativity, and Empowering Leadership: An Empirical Study. Dhaka University Journal of Business Studies, 37(1), 198-215.

Biswas, M., Ferdausy, F., \& Rahman, M.S. (2018). Role of Leadership Styles in ProblemSolving at the Private Commercial Banks of Bangladesh. BGC Trust University Journal, 5, 93-115.

Biswas, M., \& Rahman, M.S., \& Ferdausy, F. (2017). Role of Emotional Intelligence in Solving Problems at the Private Commercial Banks of Bangladesh. The Comilla University Journal of Business Studies, 4(1), 51-66.

Brotheridge, C. M. (2006). The role of emotional intelligence and other individual difference variables in predicting emotional labor relative to situational demands. Psicothema, 18.

Burns, J. M. (1978). Leadership, New York. Harper \& Row.

Campbell, J. (1990). Modeling the performance prediction problem in industrial and organizational psychology. Handbook of industrial and organizational psychology, 1(2), 687-732

Campbell, J., McCloy, R., Oppler, S., \& Sager, C. (1993). A theory of performance. Personnel selection in organizations, 35,70 .

Carmeli, A. (2003). The relationship between emotional intelligence and work attitudes, behavior, and outcomes. Journal of Managerial Psychology, 18(8), 788-813.

Cherniss, C. \& Adler, M. (2001). Promoting Emotional Intelligence in Organisations: Make Training in Emotional Intelligence effective, Alexandria, VA, ASTD

Ciarrochi, J., Forgas, J., \& Mayer, J. (2006). Emotional intelligence: A scientific approach: Philadelphia: Psychology Press.

Cooper, R., \& Sawaf, A. (1998). Executive EQ: Emotional intelligence in leadership and organizations: Perigee.

Cronbach, L. (1951). Coefficient alpha and the internal structure of test Psychometrika, 6(3), 279-334.

Dadvar, R., Mohamadrezii, M., Fathabadi, M.H. (2012). The relationship between emotional intelligence and creativity of female high school students in Baft city. Journal of Basic and Applied Scientific Research, 2(4), 4174-4183.

Downton, J. (1973). Rebel leadership: Commitment and charisma in the revolutionary process: Free Press New York.

Dries, N., \& Pepermans, R. (2007). Using emotional intelligence to identify high potential: a meta competency perspective. Leadership \& Organization Development Journal, 28(8), 749-770. 
Druskat, V.U., \& Wolff, S. (2001). Building the emotional intelligence of groups. Harvard Business Review, 79(3), 8091.

Dulewicz, V., S. \& Higgs, M. (2003). A new approach to assessing leadership dimensions, styles context. Competency and Emotional Intelligence Quarterly, 11(2), 224-232.

Ekvall, G. (1996). Organizational climate creativity and innovation. European Journal of Work and Organizational Psychology, 5(1), 105-123.

Field, A. (2005). Discovering Statistics using SPSS. London: Sage.

Franken, R.E. (1993). Human motivation. (3 ${ }^{\text {rd }}$ Eds.). Brooks/Cole Publishers Ltd.

Gardner, L. \& Stough, C. (2002). Examining the relationship between leadership and emotional intelligence in senior-level managers. Leadership \& Organization Development Journal, 23, 68-78.

George, J. M., \& Brief, A. P. (1996). Motivational agendas in the workplace: The effects of feelings on the focus of attention and work motivation. In B. M. Staw \& L. L. Cummings (Eds.), Research in organizational behavior: An annual series of analytical essays and critical reviews, Vol. 18 (p. 75-109). Elsevier Science/JAI Press.

George, J. M. (2000). Emotions and Leadership: The Role of Emotional Intelligence. Human Relations, 53 1027-1055

Gill, R. (2002). Emotional intelligence: Its role in organizational success. Training Journal, 30-34.

Goleman, D. (1995). Emotional Intelligence: Why It Can Matter More Than IQ. New York, Bantam Books.

Goleman, D. (1998a). What makes a leader? Harvard Business Review, Nov-Dee, 93-102.

Goleman, D. (1998b). Working with Emotional Intelligence, London, Bloomsbury Publishing.

Goleman, D., Boyatzis, R. \& Mckee, A. (2002). Primal Leadership: Realising the Power of Emotional Intelligence, Boston, Harvard Business School Press.

Goleman, D., Boyatzis, R., \& McKee, A. (2004). Primal leadership: Learning to lead with emotional intelligence: Harvard Business School Pr.

Hair, J., Anderson, R., Tatham, R., \& Black, W. (2003). Multivariate data analysis. Pearson Education: India.

Hellriegel, D., Jackson, S., \& Slocum Jr, J. (1999). Management, South: Western College Publishing.

Huy, Q. (1999). Emotional capability, emotional intelligence, and radical change. Academy of Management Review, 24(2), 325-345.

Koman, E., \& Wolff, S. (2008). Emotional intelligence competencies in the team and team leader. Journal of Management Development, 27(1), 55-75.

Kuncel, N. R., Hezlett, S. A., \& Ones, D. S. (2004). Academic Performance, Career Potential, Creativity, and Job Performance: Can One Construct Predict Them All? Journal of Personality and Social Psychology, 86(1), 148161.

Lewis, K. (2000). When leaders display emotion: How followers respond to the negative emotional expression of male and female leaders. Journal of Organizational Behavior, 21(2), 221-234.

Lubart, T.I. (1999). Componential models of creativity. In M.A. Runco \& S. Pritzer (Eds.), Encyclopedia of Creativity, New York: Academic Press.

Malhotra, N.K. (2002). Marketing Research: An Applied Orientation (3 $3^{\text {rd }}$ ed.). New Delhi: Pearson Education Asia.

Okpara, F.O. (2007). The value of creativity and innovation in entrepreneurship. Journal of Asia Entrepreneurship and Sustainability, 11(2), 1-15.

Olatoye, R.A., Akintunde, S.O., \& Yakasai, M.I. (2010). Emotional intelligence, creativity, and academic achievement of business administration students. Electronic Journal of Research in Educational Psychology, 8(2), 763-786.

O'Regan, N., Ghobadian, A., \& Sims, M. (2005). The link between leadership, strategy, and performance in manufacturing SMEs. Journal of Small Business Strategy, 15(2), 45-57.

Rahim, M. A., \& Marvel, M. R. (2009). A cross-cultural model of emotional intelligence and corporate entrepreneurship. Current Topics in Management: Organizational Behavior, Performance, and Effectiveness, 14, 227.

Rahim, M., Psenicka, C., Polychroniou, P., Zhao, J., Yu, C., Chan, K., Susana, K., Alves, M., Lee, C., Rahman, M.S., Ferdausy, S., \& Wyk, R. (2002). A model of emotional intelligence and conflict management strategies: a study in seven countries. International Journal, 10(4), 302-326. 
Rahim, M. A., Psenicka, C., Oh, S.Y., Polychroniou, P., Dias, J. F., Rahman, M.S., \& Ferdausy, S. (2006). Relationship between emotional intelligence and transformational leadership: A cross-cultural study. In M. A. Rahim (Ed.), Current Topics in Management (Vol. 11, pp. 223-236). New Brunswick \& London: Transaction Publishers.

Rahman, M.S. (2018). Relationships among Emotional Intelligence, Leadership Styles, and Job Performance of the Employees in Chittagong Export Processing Zone. Unpublished Ph.D. thesis, University of Chittagong, Bangladesh.

Rahman, M.S. (2010). Role of Emotional Intelligence in Leadership Styles and Job Performance. Unpublished master's thesis, University of Edinburgh, UK.

Rahman, M.S., \& Ferdausy, S. (2014). Relationship between Emotional Intelligence and Job Performance Mediated by Transformational Leadership. NIDA Development Journal, Thailand. 54(4), 123-154.

Rahman, M.S., Ferdausy, S., \& Karan, R. (2013). Assessing the Relationships between the Components of Emotional Intelligence and Job Performance: an Empirical Study. ABAC Journal, Thailand, 33(1), 1-19.

Rahman, M, Ferdausy, S, \& Uddin, M. A. (2012a). Examining the relationships between emotional intelligence and the components of transformational leadership. ABAC Journal, 32(1), 45-59.

Rahman, M.S., Ferdausy, S, \& Uddin, M. A. (2012b).Exploring the Relationship between Emotional Intelligence, Leadership, and Gender: an Empirical Study. SIU Journal of Management, 2(2), 27-57.

Rahman, M.S., Ferdausy, S., \& Karan, R. (2012c). Relationships among Emotional Intelligence, Deviant Workplace Behavior, and Job Performance: an Empirical Study. Portuguese Journal of Management Studies, 17(1), 39-61.

Robbins, S.P. (2005). Organizational Behavior. New Jersey: Pearson Prentice - Hall Inc.

Rotundo, M., \& Sackett, P. R. (2002). The relative importance of task, citizenship, and counterproductive performance to global ratings of job performance: A policy-capturing approach. Journal of Applied Psychology, 87(1), 66.

Rozell, E., Pettijohn, C., \& Parker, R. (2006). Emotional intelligence and dispositional affectivity as predictors of performance in salespeople. The Journal of Marketing Theory and Practice, 14(2), 113-124.

Salovey, P. \& Mayer, J. D. (1990). Emotional intelligence. Imagination, Cognition, and Personality, 9,185-211.

Saunders, M., Lewis, P., \& Thornhill, A. (2011). Research Methods for Business Students (5 $5^{\text {th }}$ ed.), India: Prentice-Hall.

Siedel, S., \& Rosemann, M. (2008). Creativity management - The new challenge from BPM. Retrieved from http://www. bptrends.com on 30/03/2015.

Slaski, M., \& Cartwright, S. (2002). Health, performance, and emotional intelligence: an exploratory study of retail managers. Stress and Health, 18(2), 63-68.

Sternberg, R. \& Lubart, S. (1996). Creativity as the confluence of intellectual activity, knowledge, motivation, thinking styles, U.K. http://www.elsefier.com/locate/paid. Retrieved on 30/03/2016.

Sukumaran, S., \& Sivelingam, A. (2012). The influence of emotional intelligence and creativity on work performance and commitment. Journal of Advancement of Science and Arts, 3(2), $49-74$.

Sy, T., Tram, S. E C O'hara, L. A. (2006). Relation of employee and manager emotional intelligence to job satisfaction and performance. Journal of Vocational Behavior, 68, 461-473.

Tesluk, P.E., Farr, J.L., \& Klein, S.R. (1997). Influence of organizational culture and climate on individual creativity. The Journal of Creative Behavior, 31(1), 27-41.

Tsui, A., Pearce, J., Porter, L., \& Tripoli, A. (1997). Alternative approaches to the employee-organization relationship: does investment in employees pay off? Academy of Management Journal, 40(5), 1089-1121.

Vijaykumar, R. \& Govindaraju.(2012). Creativity and Emotional Intelligence of High School Students. Journal of the Indian Academy of Applied Psychology,38(1),138-143.

Watkin, C. (2000). Developing Emotional Intelligence. International Journal of Selection and Assessment, 8, 89-99.

Weinberger, L. A. (2003). An examination of the relationship between emotional intelligence, leadership style, and perceived leadership effectiveness. An unpublished Ph.D. dissertation, University of Minnesota Minneapolis, MN.

Welbourne, T., Johnson, D., \& Erez, A. (1998). The role-based performance scale: Validity analysis of a theory-based measure. Academy of Management Journal, 540-555.

Zhang, X., \& Bartol, K. M. (2010). Linking empowering leadership and employee creativity: The influence of psychological empowerment, intrinsic motivation, and creative process engagement. Academy of Management Journal, 53(1), 107-128. 
Zhou, J., \& George, J.M. (2001). When job dissatisfaction leads to creativity: Encouraging the expression of voice. Academy of Management Journal, 44, 682-696. Attribution (CC-BY) license (http://creativecommons.org/licenses/by/4.0/). 